Only at Comic-Con 



\section{Only at Comic-Con}

Hollywood, Fans, and the Limits of Exclusivity

ERIN HANNA

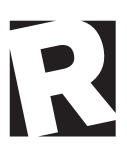

Rutgers University Press

New Brunswick, Camden, and Newark, New Jersey, and London 
Library of Congress Cataloging-in-Publication Data

Names: Hanna, Erin, 1980- author.

Title: Only at Comic-Con : Hollywood, fans, and the limits of exclusivity /

Erin Hanna.

Description: New Brunswick : Rutgers University Press, 2019. | Includes bibliographical references and index.

Identifiers: LCCN 2019009182 | ISBN 9780813594712 (cloth : alk. paper) | ISBN 97808 I3594705 (pbk. : alk. paper)

Subjects: LCSH: San Diego Comic-Con. | Comic book fans. | Comic books, strips, etc.-Marketing. | Motion pictures and comic books. | Fandom-United States. | Popular culture-United States.

Classification: LCC PN6714.H36 2019| DDC 741.5/973-dc23

LC record available at https://lccn.loc.gov/2019009182

A British Cataloging-in-Publication record for this book is available from the British Library.

Copyright (C) 2020 by Erin Hanna

All rights reserved

No part of this book may be reproduced or utilized in any form or by any means, electronic or mechanical, or by any information storage and retrieval system, without written permission from the publisher. Please contact Rutgers University Press, I06 Somerset Street, New Brunswick, NJ $\circ 890$. The only exception to this prohibition is "fair use" as defined by U.S. copyright law.

(⿻) The paper used in this publication meets the requirements of the American National Standard for Information Sciences-Permanence of Paper for Printed Library Materials, ANSI Z39.48-1992.

www.rutgersuniversitypress.org

Manufactured in the United States of America 
For the family I lost, the family I found, and the family who has always been there 
